\title{
Effect of Different Combinations of Panchagavya on Plant Yield
}

\author{
C. Sivapragasam, K. Selva Rani, S.Vanitha, A.Kowsiga, G.Lidwin Joan Jeraldine
}

\begin{abstract}
Use of organic fertilizer is being promoted as the sustainable method of agriculture for maximizing yield. In this study the six different combinations of Panchagavya are prepared and laboratory growth study is made using seed. Vigour index is used for quantifying growth rate of seeds. Result indicates that $500 \mathrm{ml}$ of tender coconut water added to the control combination gives maximum yield. The efficacy of the optimal Panchagavya combination from the lab study is applied to the field directly yielding much higher growth than the other methods used by the farmers.
\end{abstract}

Keywords : organic fertilizer, panchagavya, tender coconut water, vigour index

\section{INTRODUCTION}

$\mathrm{T}$ he usage of chemicals such as fertilizers and pesticides for the improvement of productivity of crops is rampant in the recent past. Green revolution, no doubt, has significantly contributed to the increase in crop productivity but in has also become a cause of great concern by the adverse effects it has produced by damage to ecosystem and biotic system. [1] Over the period, as awareness of ecological protection is being felt by consumers, the quality of food production is being questioned. In growing numbers, people have now started looking for safer and reliable foods produced under environmental friendly conditions. It is believed that foods produced 'organically' are much less damaging to environment and ecology and are also found to contain much higher nutritive values [2]. In fact, evidences exist that plants and crops produced organically demonstrate much higher resistance to damage by insects because they contain natural insecticides (phytochemicals) [2]. This also positively contributes to health of the consumers. Further, it is also reported that continued use of chemical fertilizers eat away

Revised Manuscript Received on December 13, 2019.

* Correspondence Author

Dr.C.Sivapragasam*,Center of water technology, department of Civil Engineering, Kalasalingam Academy of Research and Education, Krishnan kovil, Tamilnadu, India..Email: sivapragasam@klu.ac.in

Dr.S.Vanitha, department of Civil Engineering, Kalasalingam Academy of Research and Education, Krishnankoil, India. Email:svanithacivil@gmail.com.

Dr.K.Selva Rani, department of Agriculture Engineering, Kalasalingam Academy of Research and Education, Krishnankoil, India. Email: selvarani.k@klu.ac.in

A.Kowsiga, Ddepartment of Civil Engineering, Kalasalingam Academy Of Research And Education, Krishnankoil, India. Email: pushikowsi@gmail.com

G.Lidwin Joan Jeraldine, Department of Civil Engineering, Kalasalingam Academy of Research and Education, Tamilnadu, India. Email: lidwinprince98@gmail.com the fertility power of the soil making both the soil and the plants risk prone [3].

Traditionally, particularly in India, the system of agriculture involved use of vermicompost, panchagavya, organic manures and other natural modes of fertilizers which were extensively used and the food requirement for the whole population was met adequately both in quality and quantity. It is confirmed that organic manuring (cow dung, poultry manure and mustard oil cake) can play a vital role in the improvement of soil fertility and crop production [4]. Therefore, worldwide, there is a shift in paradigm towards adopting the traditional system of farming by the farmers [1] through use of organic manures which is scientifically demonstrated to improve crop productivity and soil fertility [4]. In fact, with the use of cow dung as manure, the water storage capacity of the soil also increases which, in turn, puts lesser demand on irrigation water. In this work, we mainly focus on the effectiveness of panchagavya based farming practices. Panchagavya is made up of five natural products from the cow, namely, cow dung, cow urine, cow milk, ghee and curd. Inclusion of tender coconut is usually done. A typical composition of panchagavya is given in Table 1 . There are many reported research in the use of Panchagavya. For instance, the variation in growth and yield parameters of Abelmoschus esculentus under different concentrations of panchagavya (from $1 \%$ to $7 \%$ concentration with an increment of $2 \%$ in each case besides the control condition) were studied and it is found that the physicochemical and biochemical properties were improved in 3\% concentration [6]. Similarly, the application of Vermicomspost and Panchagavya on the yield parameters of chilli (Capsicum annuum) was studied. The section of the field where the crop was grown after treatment with panchagavya performed much better in terms of enhanced growth parameters reflected in the number and size of fruits, the length of plant and number of branches when compared to the control condition subjected to the application of vermicompost [1]. The effect of Panchagavya and Sarifibani were applied on the green gram (vigna radiata), chilli (capsicum frutescens) and mustard (brassica campestris). The experimental results concluded that the crops treated with panchagavya and Sarifibani showed much better efficiency than the control condition in terms of growth in plant height, fruit length and number of seeds etc [7].

This work differs from the previous work in the sense that the focus is given on only varying the concentration of tender coconut concentration of the Panchagavya and identifying the most optimal concentration for the best yield. It is believed that the tender coconut is rich in minerals which encourage the 


\section{Effect of Different Combinations of Panchagavya on Plant Yield}

faster growth of the plants. The identification of the optimal concentration is done at the laboratory scale, and it is also implemented in the field level proving the efficacy of the proposed combination.

\section{METHODOLOGY}

Panchagavya is found to be highly useful in terms of supporting growth of the plant as well as improve plant immunity. The ingredients are collected for preparation of panchagavya which are discussed in detail as below.

\section{A. Preparation of panchagavya}

Panchagavya consists of nine products viz. cow dung, cow urine, milk, curd, jaggery, ghee, banana, tender coconut and water. As per recommendation of Tamilnadu Agricultural University, initially cow dung $350 \mathrm{~g}$ and cow ghee $50 \mathrm{~g}$ are added and a thorough mixing is done two times in a day during morning and evening hours. The mixed composition is kept for 3 days. At the end of 3 days, cow urine 500ml and water $500 \mathrm{ml}$ is added and again a thorough mixing is done twice once during morning and secondly during evening hours. This mixture is kept for 15 days under undisturbed condition. At the end of 15 days, $150 \mathrm{ml}$ of cow milk, $100 \mathrm{ml}$ of curd, $150 \mathrm{ml}$ of tender coconut water, $150 \mathrm{ml}$ jiggery and one well ripened poovan banana are added and mixed. Panchagavya becomes ready for use after 15 days. The total duration required for preparation of panchagavya is 30 days. This is taken as control combination $(\mathrm{C}-0)$. The ingredients of control combination are shown in Table I. In addition to existing combination(C-0), additional $300 \mathrm{ml}$ tender coconut water and $100 \mathrm{mg} / 1$ Indole-acetic acid (IAA) is added and is taken as combination $\mathrm{C}-1$. IAA is a plant hormone which is artificially added to the solution. The Combination $\mathrm{C}-2$ comprises of control combination $(\mathrm{C}-0)$ with the addition of $500 \mathrm{ml}$ tender coconut water and $100 \mathrm{mg} / \mathrm{l}$ Indole-acetic acid. In Combination C-3, in addition to control combination (C-0), additional $300 \mathrm{ml}$ of tender coconut water is added. In combination $\mathrm{C}-4$, in addition to control combination (C-0), additional $500 \mathrm{ml}$ of tender coconut water is added whereas in combination $\mathrm{C}-5$, in addition to control combination (C-0), additional $100 \mathrm{mg} / \mathrm{l}$ Indole-acetic acid is added.

Based on these details the various combination are differentiated from the tender coconut and IAA and are tabulated in Table 2,

Table- I: Ingredients of Panchagavya

\begin{tabular}{|l|l|l|}
\hline \multirow{2}{*}{ S.No } & \multicolumn{2}{|c|}{ Control ingredients of panchagavya } \\
\cline { 2 - 3 } & \multicolumn{1}{|c|}{ Ingredients } & \multicolumn{1}{c|}{ Quantity } \\
\hline 1 & Cow dung & $350 \mathrm{~g}$ \\
\hline 2 & Ghee & $50 \mathrm{~g}$ \\
\hline 3 & Cow urine & $500 \mathrm{ml}$ \\
\hline 4 & Water & $500 \mathrm{ml}$ \\
\hline 5 & Cow milk & $150 \mathrm{ml}$ \\
\hline 6 & Curd & $100 \mathrm{ml}$ \\
\hline 7 & Tender coconut & $150 \mathrm{ml}$ \\
\hline
\end{tabular}

\begin{tabular}{|l|l|l|}
\hline \multirow{2}{*}{ S.No } & \multicolumn{2}{|c|}{ Control ingredients of panchagavya } \\
\cline { 2 - 3 } & \multicolumn{1}{|c|}{ Ingredients } & \multicolumn{1}{c|}{ Quantity } \\
\hline 8 & Jaggery & $150 \mathrm{ml}$ \\
\hline 9 & Poovan banana & $1 \mathrm{nos}$ \\
\hline
\end{tabular}

Table- II: List of various combination of panchagavya

\begin{tabular}{|c|c|}
\hline \multirow{2}{*}{ Combination } & Various combination of panchagavya \\
\cline { 2 - 2 } & Composion \\
\hline C-1 & C-0+300ml of tender coconut+100ppm of IAA \\
\hline C-2 & C-0+500ml of tender coconut $+100 \mathrm{ppm}$ of IAA \\
\hline C-3 & C- $0+300 \mathrm{ml}$ of tender coconut \\
\hline C-4 & C- $0+500 \mathrm{ml}$ of tender coconut \\
\hline C-5 & C- $0+100 p p m$ of IAA \\
\hline
\end{tabular}

\section{B. Characteristics of panchagavya}

The $\mathrm{pH}$ and electrical conductivity test are taken for the panchagavya solution. These two parameters are important for the plant growth.

\section{Growth studies using various combination of panchagavya in lab scale}

The growth of the plant was analyzed by lab studies. The viability, vigour and physical appearances are tested for any type of seed are determined using a parameter known as Germination count. The following test procedure was followed for germination studies. The sterile petri plates were taken. It should be ensured that the Germination paper, which is used as substratum in the seed germination test, is free from bacteria, fungi and any type of toxicity. For most of the varieties of seeds and germination form, this paper also helps in ensuring optimal moisture content besides offering very high wet strength. The germination papers are soaked and are placed in the petri plate. A total of 25 seeds are placed on the soaked germination paper and the petri plates are closed. The same procedure is followed for all combination of panchagavya. The Figure 1 shows the arrangement of seeds in petri plates. The seeds are let to grow in 7 petri plates. The growth is observed after 2 to 3 days. The length of shoot and root are monitored for the seeds.

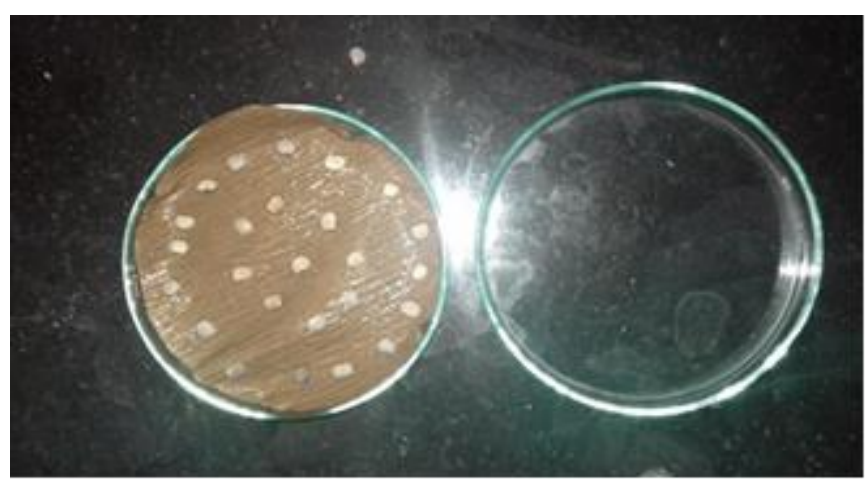

Fig. 1.Example Arrangements of seeds in petriplates

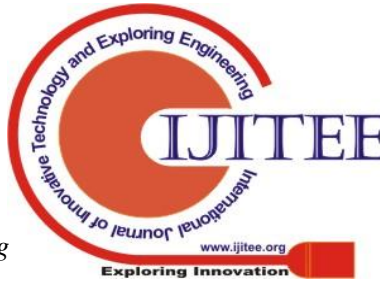




\section{RESULT AND DISCUSSION}

The concentrate solution of Panchagavya has high $\mathrm{pH}$ value and electrical conductivity. So the solution is subjected to $3 \%$ dilution after which the Panchagavya solution reached as per standard recommended value for plant growth viz., a $\mathrm{pH}$ of 5.45 and electrical conductivity value of $10.22(\mathrm{dS} / \mathrm{m})$. The result of $\mathrm{pH}$ and electrical conductivity are shown in Table III and 4. It is seen that all the combinations of Panchagavya reached the recommended value of $\mathrm{pH}$.

Table- III: pH values for different combination of panchagavya

\begin{tabular}{|l|c|c|c|c|c|c|}
\hline \multirow{2}{*}{ S.No } & \multicolumn{7}{|c|}{$\mathbf{p H}$ values } \\
\cline { 2 - 7 } & $\boldsymbol{C - 0}$ & $\boldsymbol{C - 1}$ & $\boldsymbol{C - 2}$ & $\boldsymbol{C}$-3 & $\boldsymbol{C}$-4 & $\boldsymbol{C}$-5 \\
\hline Concentrate & 4.57 & 4.6 & 4.73 & 4.4 & 4.7 & 4.68 \\
\hline 3\% dilution & 5.37 & 5.8 & 5.9 & 5.32 & 5.93 & 5.46 \\
\hline
\end{tabular}

Table- IV: Electrical conductivity values for different combination of panchagavya

\begin{tabular}{|l|c|c|c|c|c|c|}
\hline \multirow{2}{*}{ S.No } & \multicolumn{6}{|c|}{ Electrical conductivity } \\
\cline { 2 - 7 } & $\boldsymbol{C}$-0 & $\boldsymbol{C - 1}$ & $\boldsymbol{C}$-2 & $\boldsymbol{C}$-3 & $\boldsymbol{C}$-4 & $\boldsymbol{C - 5}$ \\
\hline Concentrate & 7.74 & 7.38 & 7.48 & 7.39 & 7.06 & 7.14 \\
\hline 3\% dilution & 1.45 & 1.4 & 1.3 & 1.46 & 1.25 & 1.5 \\
\hline
\end{tabular}

The growths of the plant are analyzed by the root length and shoot length and other parameters. Vigour index is important quality parameter of the seed; and activity level and seed performance during germination is determined based on the sum total of root length, shoot length, growth percentage and seedling length of the seed. The growth of the seed in germination sheet is shown in Table 5. Based on the table 5, the combinations $\mathrm{C}-4$ and $\mathrm{C}-1$ are found to reflect the effective growth of the seed.

Table- V: Laboratory growth studies for panchagavya combination

\begin{tabular}{|l|l|l|l|l|l|}
\hline \multirow{2}{*}{ S.No } & \multicolumn{5}{|c|}{$\begin{array}{c}\text { Laboratory growth studies for panchagavya } \\
\text { combination }\end{array}$} \\
\cline { 2 - 6 } & $\begin{array}{c}\text { Root length } \\
(\boldsymbol{c m})\end{array}$ & $\begin{array}{c}\text { Shoot } \\
\text { length } \\
(\boldsymbol{c m})\end{array}$ & $\begin{array}{c}\text { Grow } \\
\text { th\% } \\
(\boldsymbol{G})\end{array}$ & $\begin{array}{c}\text { Seedling } \\
\text { length } \\
(\mathbf{c m})\end{array}$ & $\begin{array}{c}\text { Vigour } \\
\text { index }\end{array}$ \\
\cline { 4 - 6 } & $\begin{array}{c}\text { (Seedling } \\
\text { length } \times \boldsymbol{G} \\
\text { \%) }\end{array}$ \\
\hline C-0 & 4.31 & 4.74 & 92 & 9.05 & 833 \\
\hline C-1 & 4.1 & 6.68 & 96 & 10.78 & 1035 \\
\hline C-2 & 3.21 & 5.79 & 94 & 9 & 846 \\
\hline C-3 & 3.42 & 4.88 & 88 & 8.3 & 730 \\
\hline C-4 & 4.82 & 5.92 & 100 & 10.74 & 1074 \\
\hline C-5 & 3.69 & 5.72 & 98 & 9.41 & 922 \\
\hline $\begin{array}{l}\text { Only } \\
\text { water }\end{array}$ & 3.94 & 3.71 & 90 & 7.65 & 689 \\
\hline
\end{tabular}

Further, as seen from Figure 2, the combination C-4 is found to have $100 \%$ growth and it has high vigour index value. Tender coconut water have high amount of auxin, gibberellins and cytokinins. This nutrient gives maximum yield and maximizes the plant growth. Next to that, combination C-1 has $96 \%$ growth and it also has high vigour index value. In this combination additional $300 \mathrm{ml}$ of tender coconut water and $100 \mathrm{mg} / \mathrm{l}$ IAA are added in control combination.

This optimal combination of Panchagavya (C-4) is also tried in the actual field directly with $3 \%$ dilution as determined in the lab scale study. The onion field is selected and panchagavya is sprayed three times with time interval between each spray kept as fifteen days. It is seen that the Panchagavya treatment has given better plant growth and yield as informed by the farmers who used it. Figure 3 shows the stages of plant growth.

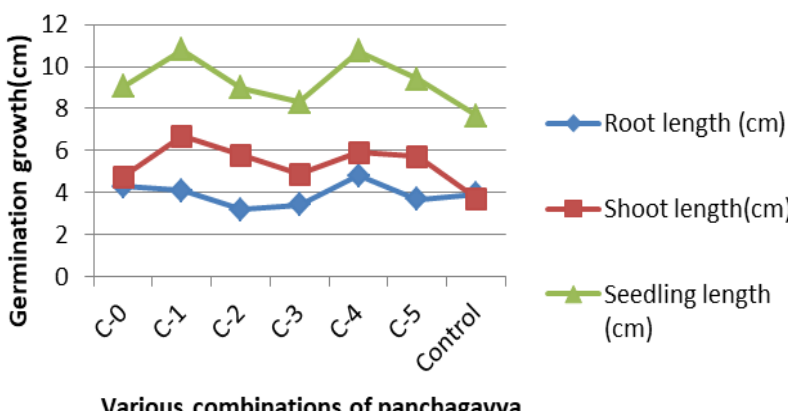

Fig. 2.Graphical representation of growth of the seed

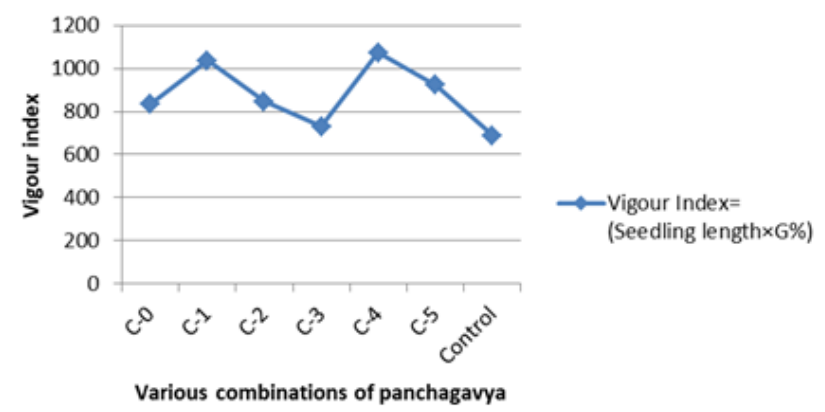

Fig. 3.Graphical representation of vigour index

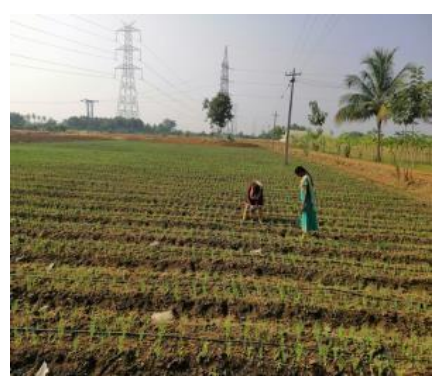

$1^{\text {st }}$ spray

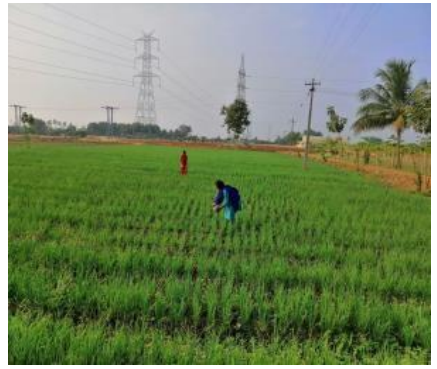

$2^{\text {nd }}$ spray
Fig. 4.Stages of plant growth

\section{CONCLUSION}

In this study, effect of different combinations of Panchagavya by varying the tender coconut water quantity on plant growth is studied and compared with current control combination used by farmers. From the result obtained, it is concluded that an addition of tender coconut as reflected in combination $\mathrm{C}-4$ 


\section{Effect of Different Combinations of Panchagavya on Plant Yield}

significantly increases the plant yield. Hence it is recommended to use tender coconut water while preparation of panchagavya solution and while preparation of organic fertilizer.

\section{REFERENCES}

1. Rao, Mudiganti Ram Krishna, M. Sathish Kumar, and Neema Kumari Jha. "Comparative yield analysis of Chilli (Capsicum annuum L.) by application of Vermicompost and Panchagavya." Journal of Chemical and Pharmaceutical Research 7, no. 9 (2015): 319-323.

2. Rembiałkowska, Ewa. "Quality of plant products from organic agriculture." Journal of the Science of Food and Agriculture87, no. 15 (2007): 2757-2762.

3. Oad, F. C., U. A. Buriro, and S. K. Agha. "Effect of organic and inorganic fertilizer application on maize fodder production." Asian J. Plant Sci 3, no. 3 (2004): 375-377.

4. Ullah, M. S., M. S. Islam, M. A. Islam, and T. Haque. "Effects of organic manures and chemical fertilizers on the yield of brinjal and soil properties." Journal of the Bangladesh Agricultural University 6, no. 2 (2008):271-276

5. Yong, Jean W., Liya Ge, Yan Fei Ng, and Swee Ngin Tan. "The chemical composition and biological properties of coconut (Cocos nucifera L.) water." Molecules 14, no. 12 (2009): 5144-5164.

6. Rakesh, Suchitra, S. Poonguzhali, B. Saranya, S. Suguna, and K. Jothibasu. "Effect of panchagavya on Growth and Yield of Abelmoschus esculentus cv. Arka Anamika." Int. J Curr. Microbiol. App. Sci 6, no. 9 (2017): 3090-3097.

7. Ali, M. N., S. Ghatak, and T. Ragul. "Biochemical analysis of Panchagavya and Sanjibani and their effect in crop yield and soil health." J. Crop Weed 7, no. 2 (2011): 84-86.

8. Yong, Jean W., Liya Ge, Yan Fei Ng, and Swee Ngin Tan. "The chemical composition and biological properties of coconut (Cocos nucifera L.) water." Molecules 14, no. 12 (2009): 5144-5164.

\section{AUTHORS PROFILE}

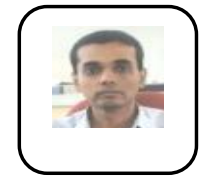

Dr. K.Sivapragasam has completed his graduation and post-graduation from IIT-Roorkee and IIT-Delhi respectively. He completed his $\mathrm{PhD}$ from NUS, Singapore. He has 2 years of industry experience and more than 17 years of teaching experience. He has completed 3 sponsored research projects from various funding agencies and published more than 70 papers in peer reviewed journals and conferences..

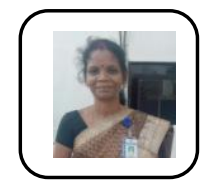

Dr. K.Selvarani the author did her Doctorate in Agricultural College and Research Institute, Madurai, Tamil Nadu, India. She has authored three book chapters, 20 plus research papers and popular articles. She has presented five papers in various National and International conferences. Currently she is serving as Assistant Professor, Seed Science and Technology, School of Agricultural Sciences, Kalasalingam Academy of Research and Education, Tamil Nadu, India.

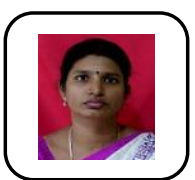

Dr. S.Vanitha has completed her graduation and post -graduation from Government of College of engineering, Tirunelveli and Arulmigu Kalasalingam College of Engineering. She has completed her $\mathrm{PhD}$ in Kalasalingam Academy of Research And Education. She conferences. has published more than 20 papers in journals and

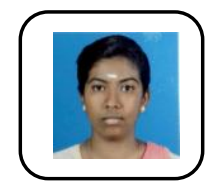

A.Kowsiga is currently pursuing her final year undergraduation in the Department of Civil Engineering, Kalasalingam Academy of Research And Education. She has keen interest in the field of environment and water resources engineering.

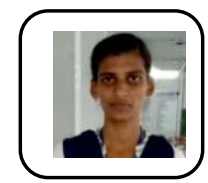

G.Lidwin Joan Jeraldine is currently pursuing her final year undergraduation in the Department of Civil Engineering, Kalasalingam Academy of Research And
Education. She has keen interest in the field of environment and water resources engineering. 